\title{
Coarse root growth of Veronese poplar trees varies with position on an erodible slope in New Zealand
}

\author{
I. R. McIvor · G. B. Douglas · R. Benavides
}

Received: 16 December 2007 / Accepted: 4 January 2009/Published online: 30 January 2009

(C) Springer Science+Business Media B.V. 2009

\begin{abstract}
Poplars are commonly planted on moist, unstable pastoral hill country to prevent or reduce soil erosion, thereby maintaining hillslope integrity and pasture production. Mechanical reinforcement by poplar root systems aids slope stabilisation, particularly when the roots are anchored into the fragipan or underlying rock. Total root length, mass and distribution of coarse roots ( $\geq 2 \mathrm{~mm}$ diameter) were determined for three Populus deltoides $\times$ nigra 'Veronese' trees in their 12th growing season after being planted as $3 \mathrm{~m}$ poles at upper slope (TU), mid-slope (TM) and lower slope (TL) positions on an erodible hillslope near Palmerston North in the southern North Island. Most of the roots were distributed in the top $40 \mathrm{~cm}$ of soil. Depth of penetration of vertical roots was dependent on slope position and limited by the available depth of the soil above a fragipan $(0.35 \mathrm{~m}$ at the upper slope to $1.4 \mathrm{~m}$ at the lower slope). Roots penetrated the fragipan at the upper slope position where the soil depth was shallowest, and at the mid-slope, but not the lower slope
\end{abstract}

I. R. McIvor ( $\square)$

HortResearch, Private Bag 11 030, Palmerston North, New Zealand

e-mail: imcivor@hortresearch.co.nz

G. B. Douglas

AgResearch, Private Bag 11 008, Palmerston North,

New Zealand

R. Benavides

SERIDA Área de Sistemas de Producción Animal, 33300 Villaviciosa, Asturias, Spain position. Total coarse root length was $287.9 \mathrm{~m}$ for TU, $1,131.3 \mathrm{~m}$ for TM and $1,611.3 \mathrm{~m}$ for TL, and total coarse root dry mass (excluding root crown) was $8.15 \mathrm{~kg}$ for TU, $38.77 \mathrm{~kg}$ for TM and $81.35 \mathrm{~kg}$ for TL.

Keywords Hill country, poplar .

Slope $\cdot$ Soil conservation - Soil stability ·

Root development

\section{Introduction}

Steep hills below $1,000 \mathrm{~m}$ occupy at least $40 \%$ of New Zealand's land surface. These lowland steeplands are commonly known as New Zealand hill country (Blaschke et al. 1992). Approximately 60\% of farmland in New Zealand is used for sheep and beef farming (Statistics NZ 2007) and the majority of this area is hill country. Decreasing slope is generally associated with increasing soil fertility due in part to increased nutrient transfer by grazing animals and increased soil moisture status from greater water retention ability or reduced incidence of rainfall runoff on easier slopes (Ball et al. 1982).

Poplars are commonly planted on moist, unstable hill country to prevent or reduce soil erosion (Wall et al. 1997; Wilkinson 1999). Planting patterns and materials vary considerably. They range from high density plantings (up to 1,500 trees $\mathrm{ha}^{-1}$ ) of unrooted 
$1 \mathrm{~m}$ stakes on more actively eroding and unstable sites retired from grazing, to widely spaced (25150 trees $\mathrm{ha}^{-1}$ ) hillslope planting of $3 \mathrm{~m}$ poles on partly unstable grazed hill country. Slips often occur just below gently sloping hillcrests where downhill slopes become steeper, frequently because of seepage water from the ridges flowing over impervious layers. One or two rows of poplars or tree willows spaced 8$12 \mathrm{~m}$ apart are frequently planted in this change of slope area (Wilkinson 1999).

Two principal functions of tree root systems are the acquisition of soil-based resources and the provision of stability to maintain the tree's upright structure (Fitter 2002). The shape of a root system is largely determined by site conditions e.g. water table height, exposure to wind (Stokes and Matteck 1996; Nicoll and Ray 1996), presence of a hard pan (Danjon et al. 2005; McIvor et al. 2008), slope (Di Iorio et al. 2005), soil nutrient gradients (Friend et al. 2000).

Plant roots are believed to play an essential role in slope stabilization and erosion control (Reubens et al. 2007; Gray and Solir 1996; Watson et al. 1999). Root networks vary with species resulting in some tree species with more extensive networks being more suitable for hillslope stabilisation than others are. For this reason and also because of the ease of vegetative establishment, in New Zealand pastoral hill country, poplars and willows are generally favoured for soil conservation (Wilkinson 1999; Douglas et al. 2006a, b) ahead of other species such as endemic species. Poplars are used more extensively than willows on hillslopes because they are frequently more tolerant of the periodic soil water deficits that occur in summer. Systems have been developed that aid the rapid establishment and growth of poplars in the presence of grazing animals (McIvor et al. 2008). The distribution and morphology of the poplar root system have a key influence on soil physical properties, such as soil strength and soil water content, which in turn influence both soil stability and pasture growth. Therefore it is important to understand how the distribution of the poplar root system changes with time and with position on the slope. Rootreinforced soil has a greater resistance to continued deformation, without loss of residual strength, than soil alone (Gray and Leiser 1982; Davidson et al. 1991). Direct-shear tests of soil-root composites have demonstrated that soil shear strength increases linearly with increasing root mass (Waldron and Dakessian 1981; Wu et al. 1988), and that root reinforced soil is generally stronger and more ductile than fallow soil (Bransby et al. 2006). Tree root systems must be large enough to transfer forces into the ground and strong enough in highly stressed areas to prevent breakage (Stokes and Matteck 1996; Stokes et al. 1998). Consequently the distribution of large structural roots will reflect the nature and direction of stresses experienced by the tree.

Numerous studies of root distribution in tree species have been reported (Davidson et al. 1991; Malhotra et al. 1985; Watson et al. 1999; Eamus et al. 2002; Di Iorio et al. 2005; De Baets et al. 2007) including several studies in Populus (Tandon et al. 1991; Puri et al. 1994; Burgess et al. 1997; Snyder and Williams 2007; Fang et al. 2007; McIvor et al. 2008). A study of root mass production and distribution for Populus deltoides Marshall in a mixed density agroforestry system on irrigated plain land in India focused primarily on organic productivity and mineral cycling (Tandon et al. 1991), another Indian study determined competition of Populus deltoides with agricultural crops (Puri et al. 1994) and a third study focused on changes in root distribution with tree age for Populus deltoides $\times$ nigra 'Veronese' growing on a slope (McIvor et al. 2008). Burgess et al. (1997) investigated root distribution of 4-yearold Populus deltoides $\times$ trichocarpa growing in a silvoarable system using soil trenches. Snyder and Williams (2007) showed that in Populus fremontii water stress reduced coarse root growth and promoted redistribution of fine roots, a finding relevant to understanding root distribution of poplars on hill slopes experiencing summer drought. Root biomass studies have been reported for Pinus radiata D. Don and Kunzea ericoides (A. Rich) var. ericoides J. Thompson (Watson et al. 1999) and for Quercus pubescens Willd. (Di Iorio et al. 2005). Gottlicher et al. (2008) demonstrated that lateral root spread can be determined in forest ecosystems for mature trees by indirect methods using stable isotopes or ectomycorrhizal sporocarp distribution, however, patterns of distribution of active roots were not easy to predict and their results indicated that either some trees had very small root systems or that their root systems were highly asymmetric, a situation verifiable by excavation. Genet et al. (2008) in a study of root evolution using soil cores in managed close-spaced 
Cryptomeria japonica plantations aged 9, 20 and 30 years growing on erosion-prone steep slopes found significant differences in root density and slope stability between the different stands depended on stand age and structure, and recognised additional data on coarse root architecture and distribution as trees age would benefit understanding and modelling of tree effectiveness in stabilising soil on slopes. Tree root systems are plastic in nature, responding to changes in environmental conditions. Coarse root architecture in Pinus pinaster on moderately deep soils showed considerable structural adaptation to the prevailing wind and soil profile e.g. high water table, hardpan (Danjon et al. 2005). Friend et al. (2000) showed that for some poplar clones root growth was stimulated by nutrient-enriched patches of soil. Snyder and Williams (2007) found that changes in fine root biomass in Populus fremontii were associated with changes in water-source use for water stressed plants, and that removal of leaves reduced root growth relative to shoot growth. Allocation of carbon to root systems can vary in response to environmental conditions. Competition with other species can produce differences in root distribution within the soil profile. An example of this was reported by Mulia and Dupraz (2006) investigating the spatial distribution of fine roots of two deciduous tree species, hybrid walnut trees (Juglans regiaxnigra cv. NG23) and hybrid poplars (Populus euramericana cv. 1214) growing with or without annual winter intercrops for 10 years on deep alluvial soils. The distribution of live fine roots from the walnut and poplar trees was patchy and sometimes unexpected. In the tree-only stands, fine root profiles followed the expected pattern, as fine root density decreased with increasing depth and distance from the tree trunk. However, many fine root profiles under intercropped trees were uniform with depth, and some inverse profiles were observed. They considered these distributions may result from a high degree of plasticity of tree root systems to sense and adapt to fluctuating and heterogeneous soil conditions. The distortion of the tree root system was more pronounced for the walnut trees that only partially explored the soil volume: in the tree-only stand, the walnut rooting pattern was very superficial, but in the intercropped stand walnut trees developed a deep and dense fine root network below the crop rooting zone. The larger poplars explored the whole available soil volume, but the intercrop significantly displaced the root density from the topsoil to layers below $1 \mathrm{~m}$ depth.

However, there appear to be no published studies that determine the root direction, distribution and size of poplar roots up a slope in wide spaced hill country plantings. Knowledge of the spatial and temporal root development of poplars will help farmers and other land managers to determine the spacings and positions of plantings for optimum effectiveness for soil conservation, and will provide a more informed basis for ongoing management strategies.

Many studies of tree root distribution focussing on the roots with diameter $\geq 2 \mathrm{~mm}$, have either referred to the roots as structural or coarse. We have used the term 'coarse' since it contrasts with the usual description for roots $<2 \mathrm{~mm}$ diameter of 'fine', and leaves the term 'structural' for other uses.

This study aimed to determine the distribution and mass of coarse roots ( $\geq 2 \mathrm{~mm}$ diameter) of single, widely spaced Populus deltoides $\times$ P. nigra $\mathrm{L}$. 'Veronese' trees, of the same age, growing at three positions up an erodible hillslope, to test the hypothesis that the linear relationships between $d b h$ and the parameters, root biomass and root length (McIvor et al. 2008) is valid for clonal poplar trees growing in different positions up a slope and of larger size, and to determine how root development is modified by change in soil properties.

\section{Materials and methods}

Site and tree species

The excavations were conducted in a poplar silvopastoral block established on an east-facing hillslope $\left(15-25^{\circ}\right)$ at AgResearch's Ballantrae Hill Country Research Station, near Palmerston North, in the southern North Island of New Zealand (latitude S $40.3^{\circ}$, longitude $\mathrm{E} 175.8^{\circ}$, altitude $120 \mathrm{~m}$ a.s.l.). The soil type is a Kumeroa hill soil classified as Typic Dystrochrepts related to yellow-brown earths and yellow-grey earth intergrades (Hewitt 1998). These soils are primarily fine sandy loams with a clay content of $18-20 \%$, low organic matter content, and low macroporosity formed on a shallow layer of tertiary sandstone, siltstone or mudstone. Subsurface water flowing downslope across the tertiary layer makes the hillsides vulnerable to soil slippage during 
periods of heavy rain and high soil water content. The climate is temperate with mean daily air temperatures ranging from $6.8^{\circ} \mathrm{C}$ in June (winter) to $18.1^{\circ} \mathrm{C}$ in January (summer). The site has mean annual rainfall of $1,250 \mathrm{~mm}$ and is exposed to prevailing westerly winds. The hillslope had experienced repeated slippage since being converted for pastoral farming and new slips have occurred since the trees were planted. The site is regularly grazed by sheep, so the slope is interspersed with sheep tracks that modify runoff, soil depth upslope and recontour slips.

The trees were hybrid poplar (Populus deltoides $\times$ P. nigra L.) clone 'Veronese' and were established from $3 \mathrm{~m}$ poles (McIvor et al. 2008) in 1995 at $8 \mathrm{~m} \times 8 \mathrm{~m}$ spacing $\left(156\right.$ trees ha $\left.^{-1}\right)$. The poles were planted to a standard depth of $60 \mathrm{~cm}$ where possible and had a diameter at breast height $(d b h ; 1.4 \mathrm{~m}$ above the ground on the upslope side of the trunk) of approximately $6.5 \mathrm{~cm}$ at planting.

Excavation procedure, measurements, and data analysis

Three trees aged 11.5 year were excavated during the summer of 2007 from a part of the plantation where there were no recent slips, one at upper slope $\left(32.0^{\circ}\right.$ slope), henceforth referred to as TU, one at mid-slope $\left(28.6^{\circ}, \mathrm{TM}\right)$ and one in the accumulation zone on the lower part of the slope $\left(21.8^{\circ}\right.$, TL). Tree TU did not have adjacent trees because of fatalities since planting however, TM and TL were mostly surrounded by other spaced trees.

Each tree was cut horizontally at the point immediately above where the top-most root emerged from the trunk. For each tree, height and $d b h$ were measured, and the tree components above the cut were harvested and measured. Sub-samples were oven-dried $\left(70^{\circ} \mathrm{C}\right.$ to constant weight) to determine component dry weights. The area around the root crown (McIvor et al. 2008) was marked in a $2 \mathrm{~m} \times 2 \mathrm{~m}$ grid extending $10 \mathrm{~m}$ upslope, downslope, and left and right of the root crown, giving a marked area of $20 \mathrm{~m} \times 20 \mathrm{~m}$.

Those roots growing from the root crown and extending in a vertical or near vertical direction were identified as vertical roots (Wilson 1975). Roots growing horizontally from the root crown and branching at irregular intervals were identified as radial roots (Wilson 1975). Vertical roots attached to radial roots were defined as sinker roots (Wilson 1975) and were included as part of the radial root component for statistical purposes. Vertical and radial roots were measured from their point of origin on the root crown.

Radial roots were dry excavated, digging along the course followed by the roots in the soil using spade and trowel, and the path of each root was mapped on graph paper (Puri et al. 1994). Roots were grouped into diameter classes of 2-5 mm, 5-10 mm, 10$20 \mathrm{~mm}, 20-40 \mathrm{~mm}, 40-80 \mathrm{~mm}$ and $>80 \mathrm{~mm}$ for ease of sorting and analysis, as in other root excavation studies (Watson and O'Loughlin 1990; Puri et al. 1994). As each root was mapped, changes in root diameter from one class to another were recorded along its length. The depth of the root below the surface was also recorded along its length, together with the length and depth of any root branching from the main root. Fresh weights and root length were recorded for each diameter class. All roots in each diameter class were dried at $70^{\circ} \mathrm{C}$ to a constant weight. Fine roots $(<2 \mathrm{~mm}$ diameter $)$ were not measured.

All vertical roots were excavated by hand except in the case of TL when a mechanical digger was used for the final excavation stage. Root length, diameter and depth were measured and root mass calculated as before. Total root mass comprised the dry weights of vertical and radial roots and it excluded root crown dry weight because this was not a true root per se, and its inclusion in the $>80 \mathrm{~mm}$ diameter category would have biased the interpretation of root dynamics in this category.

\section{Soil sampling}

The soil was sampled within $2 \mathrm{~m}$ of each of the tree positions on the slope. Intact cores were taken from the centre of the horizon at each selected depth for determining bulk density and volumetric water content (VWC). Additional samples were collected at similar depths for nutrient analysis. The intact cores were dried at $105^{\circ} \mathrm{C}$ to a constant weight, weighed and bulk density and volumetric water content calculated. The other samples were assayed for soil pH (1:2.1 soil:water suspension), Olsen-extractable phosphorus (P), extractable sulphate sulphur (S), and quick test concentrations of calcium $(\mathrm{Ca})$, magnesium $(\mathrm{Mg})$, and potassium $(\mathrm{K})$, following extraction with 
$1 \mathrm{~N}$, neutral $(\mathrm{pH} 7)$ ammonium acetate (Mountier et al. 1966).

Intact cores $(n=3)$ were also taken on a wellworn sheep track on the lower slope at 7.5 and $12.5 \mathrm{~cm}$ depth in the same way to ascertain whether soil compaction along sheep tracks might influence tree root extension. The samples were dried at $105^{\circ} \mathrm{C}$ to a constant weight, weighed and bulk density calculated. For analysis of nutrient content, soil was sampled at $0-75 \mathrm{~mm}$ depth, mixed thoroughly, and sent for analysis.

\section{Ovoidness}

For the roots with mean diameter $>80 \mathrm{~mm}$ ovoidness, used as an indicator of root stress, was calculated by dividing the large diameter by the small diameter.

Statistical analyses

ANOVA was used to detect significant differences in soil bulk density at different positions on the slope and in the sheep tracks. Coarse root mass and coarse root length of three trees previously excavated at this site from the lower slope (McIvor et al. 2008) were included with the data from the three trees excavated up the slope, and regression analysis was used to calculate logarithmic relationships with $d b h$ for both root length and root mass $(n=6)$. For these analyses the root crown was excluded. The ratio of root mass to trunk cross-sectional area (calculated from $d b h$ ) was calculated for all three trees. The ratio of belowground mass (root crown, vertical roots, radial roots) to above-ground mass (trunk, branches and leaves), henceforth referred to as root:shoot ratio $(\mathrm{R} / \mathrm{S})$, was calculated for all trees, as was the percentage of total tree DM contained below ground.

\section{Results}

Dimensions of the excavated trees

Tree height ranged from $11.15 \mathrm{~m}$ for TU to $13.40 \mathrm{~m}$ for TL (Table 1) and height of the two trees located lower on the slope were $16 \%$ (TM) and 20\% (TL) greater than for TU. Both trees lower on the slope also had thicker trunks with $d b h$ of TM being $44 \%$ greater than for TU whilst TL exceeded TU by $53 \%$. Trunk cross-sectional area of TL at $661 \mathrm{~cm}^{2}$ was 2.4 times greater than for TU at $281 \mathrm{~cm}^{2}$. Highest leaf area was $175.0 \mathrm{~m}^{2}$ for TL which was 17 times greater than for TU and 10 times greater than for TM (Table 1).

Soil bulk density, volumetric water content and nutrient status

Soil depths to the fragipan were $0.35-0.4 \mathrm{~m}, 0.3-$ $0.8 \mathrm{~m}$ and $0.6-1.4 \mathrm{~m}$ at the upper slope, mid-slope and lower slope positions, respectively. Bulk density at $7.5 \mathrm{~cm}$ soil depth was very similar across the three slope positions and there was a general trend of increasing density with soil depth (Table 2). A notable anomaly occurred at the lower slope position where bulk density at $112.5 \mathrm{~cm}$ depth was $0.2 \mathrm{~g} \mathrm{~cm}^{-3}$ less than at $82.5 \mathrm{~cm}$ depth. Soil sampled at the latter depth had a bulk density of $1.72 \mathrm{~g} \mathrm{~cm}^{-3}$ which was the highest of all samples. There was a layer of buried topsoil at the $112.5 \mathrm{~cm}$ depth sample site on the lower slope where the bulk density was lower (Table 2). At soil depths of 12.5, 22.5, and $52.5 \mathrm{~cm}$, variation between locations was less than $0.25 \mathrm{~g} \mathrm{~cm}^{-3}$. Bulk densities of the soil on the sheep tracks $\left(1.16 \pm 0.07 \mathrm{~g} \mathrm{~cm}^{-3}\right.$ at $7.5 \mathrm{~cm}$ depth and $1.24 \pm 0.05 \mathrm{~g} \mathrm{~cm}^{-3}$ at $12.5 \mathrm{~cm}$ depth, $n=3$ ) were

Table 1 Dimensions of three excavated 'Veronese' poplar trees aged 11.5 year growing at upper (TU), mid (TM) and lower (TL) positions on a slope near Palmerston North, New Zealand

\begin{tabular}{|c|c|c|c|c|c|c|c|c|}
\hline Tree & $\begin{array}{l}\text { Height } \\
(\mathrm{m})\end{array}$ & $\begin{array}{l}d b h \\
(\mathrm{~cm})\end{array}$ & $\begin{array}{l}\text { Above ground } \\
\text { mass (kg DM) }\end{array}$ & $\begin{array}{l}\text { Root length } \\
\text { (m) }\end{array}$ & $\begin{array}{l}\text { Root mass } \\
(\mathrm{kg} \mathrm{DM})\end{array}$ & $\begin{array}{l}\text { Root crown: } \\
\text { mass (kg DM) }\end{array}$ & $\begin{array}{l}\text { Trunk cross- } \\
\text { section }\left(\mathrm{cm}^{2}\right)\end{array}$ & $\begin{array}{l}\text { Leaf area } \\
\left(\mathrm{m}^{2}\right)\end{array}$ \\
\hline TU & 11.15 & 18.9 & 61.48 & 293.2 & 8.15 & 6.60 & 281 & 10.3 \\
\hline $\mathrm{TM}$ & 12.95 & 27.2 & 210.87 & $1,131.3$ & 38.77 & 16.50 & 581 & 102.3 \\
\hline TL & 13.40 & 29.0 & 260.79 & $1,611.3$ & 81.35 & 18.18 & 661 & 175.0 \\
\hline
\end{tabular}

$d b h$ diameter at breast height, $D M$ dry matter 
Table 2 Soil bulk density ( $\rho$ ) and volumetric water content (VWC) at up to six depths at three positions on a slope near Palmerston North, New Zealand

\begin{tabular}{|c|c|c|c|c|c|c|}
\hline \multirow[t]{2}{*}{ Depth (cm) } & \multicolumn{2}{|l|}{ Upper slope } & \multicolumn{2}{|l|}{ Mid slope } & \multicolumn{2}{|l|}{ Lower slope } \\
\hline & $\rho\left(\mathrm{g} \mathrm{cm}^{-3}\right)$ & VWC $\left(\mathrm{g} \mathrm{cm}^{-3}\right)$ & $\rho\left(\mathrm{g} \mathrm{cm}^{-3}\right)$ & VWC $\left(\mathrm{g} \mathrm{cm}^{-3}\right)$ & $\rho\left(\mathrm{g} \mathrm{cm}^{-3}\right)$ & $\operatorname{VWC}\left(\mathrm{g} \mathrm{cm}^{-3}\right)$ \\
\hline 7.5 & $1.25 \pm 0.01$ & $0.35 \pm 0.04$ & $1.23 \pm .05$ & $0.31 \pm 0.02$ & $1.22 \pm 0.04$ & $0.3 \pm 0.02$ \\
\hline 12.5 & $1.33 \pm 0.02$ & $0.32 \pm 0.04$ & $1.44 \pm 0.09$ & $0.28 \pm 0.01$ & $1.20 \pm 0.02$ & $0.31 \pm 0.01$ \\
\hline 22.5 & $1.62 \pm 0.02$ & $0.29 \pm 0.01$ & $1.42 \pm 0.04$ & $0.24 \pm 0.01$ & $1.65 \pm 0.05$ & $0.26 \pm 0.01$ \\
\hline 32.5 & $1.55 \pm 0.09$ & $0.29 \pm 0.02$ & ND & ND & ND & ND \\
\hline 52.5 & ND & ND & $1.66 \pm 0.07$ & $0.21 \pm 0.01$ & $1.57 \pm 0.12$ & $0.29 \pm 0.02$ \\
\hline 82.5 & ND & ND & ND & ND & $1.72 \pm 0.11$ & $0.27 \pm 0.02$ \\
\hline 112.5 & ND & ND & ND & ND & $1.52 \pm 0.03$ & $0.38 \pm 0.01$ \\
\hline
\end{tabular}

Values are means $\pm 1 \mathrm{SD}$

$N D$ not determined

not significantly greater than the rest of the slope bulk densities at these depths $(P=0.2)$.

Soil $\mathrm{pH}$ at all locations and depths was 5.8-6.2 except at 0-7.5 $\mathrm{cm}$ depth at the upper (5.6) and lower slope (5.4) locations (Table 3). Availability of P, S, $\mathrm{K}, \mathrm{Ca}$ and $\mathrm{Mg}$ (Table 3) was low though comparable with measurements reported at other locations at Ballantrae (Hazard et al. 2001; Cowie 1983).

Volumetric water content (Table 2) was similar at the same depths at mid-slope and lower slope locations, but higher at the upper slope location. The highest VWC $\left(0.38 \mathrm{~g} \mathrm{~cm}^{-3}\right)$ was measured at $1.125 \mathrm{~m}$ depth at the lower slope location, and the lowest $\left(0.21 \mathrm{~g} \mathrm{~cm}^{-3}\right)$ at $0.525 \mathrm{~m}$ at the mid-slope location.

Root mass and root length

The TL tree had a coarse root mass of $81.35 \mathrm{~kg}, 10 \times$ that of TU (Table 4) and twice that of TM. The proportional difference in root length was smaller TL having $5 \times$ and $1.4 \times$ the root length of TU and TM, respectively. There was little difference in the percentage distribution of root length in the various size classes. However, the percentage distribution of root biomass was strongly influenced by the

Table 3 Soil pH and nutrient status at three or five depths at three positions on a slope near Palmerston North, New Zealand in February 2007

\begin{tabular}{|c|c|c|c|c|c|c|c|}
\hline \multirow[t]{2}{*}{ Position on slope } & \multirow[t]{2}{*}{ Depth $(\mathrm{cm})$} & \multirow[t]{2}{*}{$\mathrm{pH}$} & \multirow[t]{2}{*}{ Olsen P (ug/g) } & \multirow[t]{2}{*}{$\mathrm{S}\left(\mathrm{SO}_{4}\right)(\mathrm{ug} / \mathrm{g})$} & \multicolumn{3}{|c|}{ Exchangeable cations (me/100 g soil) } \\
\hline & & & & & $\mathrm{K}$ & $\mathrm{Ca}$ & $\mathrm{Mg}$ \\
\hline \multirow[t]{3}{*}{ Upper } & $0-7.5$ & 5.6 & 14 & 11 & 0.3 & 1.8 & 1.9 \\
\hline & $15-20$ & 6.1 & 1 & 3 & 0.2 & 1.2 & 1.1 \\
\hline & $25-30$ & 6.1 & 3 & 3 & 0.2 & 1.1 & 1.2 \\
\hline \multirow[t]{3}{*}{ Mid } & $0-7.5$ & 6.0 & 7 & 6 & 0.3 & 2.3 & 2.2 \\
\hline & $15-20$ & 5.9 & 3 & 1 & 0.2 & 1.2 & 0.8 \\
\hline & $45-50$ & 6.1 & 5 & $<1$ & 0.1 & 1.4 & 1.2 \\
\hline \multirow[t]{5}{*}{ Lower } & $0-7.5$ & 5.4 & 10 & 6 & 0.2 & 1.4 & 1.4 \\
\hline & $15-20$ & 5.8 & 4 & 1 & 0.1 & 1.2 & 0.9 \\
\hline & $45-50$ & 6.0 & 3 & 1 & 0.1 & 1.5 & 1.1 \\
\hline & $75-80$ & 6.2 & 2 & 2 & 0.1 & 1.7 & 1.2 \\
\hline & $105-110$ & 6.2 & 3 & 3 & 0.1 & 1.1 & 1.0 \\
\hline
\end{tabular}


Table 4 Length and mass of coarse roots ( $\geq 2 \mathrm{~mm}$ diameter) in 6 diameter classes for single trees of 'Veronese' poplar aged 11.5 year growing at upper (TU), mid (TM) and lower (TL) positions on a slope near Palmerston North, New Zealand

\begin{tabular}{|c|c|c|c|c|c|c|}
\hline \multirow[t]{2}{*}{ Root diameter mm } & \multicolumn{3}{|c|}{ Root length (m) } & \multicolumn{3}{|c|}{ Root mass (kg DM) } \\
\hline & $\mathrm{TU}$ & $\mathrm{TM}$ & TL & $\mathrm{TU}$ & TM & $\mathrm{TL}$ \\
\hline $2<5$ & $168.7(58)$ & $644.7(57)$ & $976.5(61)$ & $0.55(7)$ & $1.44(4)$ & $2.36(3)$ \\
\hline $5<10$ & $56.9(19)$ & $265.5(24)$ & $379.1(24)$ & $0.96(12)$ & $2.49(6)$ & $4.46(6)$ \\
\hline $10<20$ & $44.3(15)$ & $144.7(13)$ & $175.7(11)$ & $1.66(20)$ & $6.19(18)$ & $8.63(11)$ \\
\hline $20>40$ & $16.3(6)$ & $59.2(5)$ & $53.7(3)$ & $2.22(27)$ & $9.36(24)$ & $9.34(12)$ \\
\hline $40<80$ & $6.9(2)$ & $13.5(1)$ & $18.4(1)$ & $2.12(26)$ & $9.29(24)$ & $12.45(15)$ \\
\hline$>80$ & $0.1(<1)$ & $3.7(<1)$ & $7.9(<1)$ & $0.64(8)$ & $10.00(26)$ & $44.11(54)$ \\
\hline Total & 293.2 & 1131.3 & 1611.3 & 8.15 & 38.77 & 81.35 \\
\hline
\end{tabular}

Figures in brackets are percentages calculated from data within each column

investment in the large roots close to the stump, which increased markedly from TU to TL.

Root distribution and interaction

with the underlying fragipan

Radial distribution of coarse roots was variable around the trees at different positions up the slope, and differed between upslope and downslope sides of the trees (Fig. 1). Roots changed direction and depth frequently and they crossed each other regularly. Roots in the downslope direction were mostly located at $0-30 \mathrm{~cm}$ depth and changed depth less often than roots growing upslope.

Some roots of TU and TM penetrated cracks in the fragipan and extended both upslope and downslope within the fragipan between the sedimentary layers (Fig. 2). These roots were up to $20 \mathrm{~mm}$ diameter, flattened and extended for distances exceeding $2 \mathrm{~m}$ between the mudstone layers within the fragipan. They were extremely difficult to excavate. When the roots divided, both branches extended in the same planar fashion. Many fine roots grew from these roots, frequently terminating in dense, net-like structures. No roots of TL had grown into the fragipan.

\section{Root morphology and development}

Radial root development varied between the three trees (Fig. 1). For TU where the profile across the slope was punctuated with ridges and hollows, root extension uphill appeared to favour deeper soil in the hollows (no data given). There were three radial roots $>80 \mathrm{~mm}$ in diameter (cross-sectional dimensions of
$93 \times 170,83 \times 111$ and $83 \times 138 \mathrm{~mm})$ extending at $190^{\circ}, 270^{\circ}$ and $290^{\circ}\left(0^{\circ}\right.$ being north) from the trunk before branching or re-orientating. The mean ovoidness of these roots was 1.61 (range 1.34-1.83). The major vertical root was $210 \mathrm{~mm}$ in diameter and extended down to the fragipan where it divided in to a large number of small roots that grew along the top of the fragipan. Most large roots originating downslope of the trunk were vertical roots, the largest of which had diameters of $32,34,25$ and $32 \mathrm{~mm}$. None of these vertical roots penetrated the fragipan, instead ending in a fan of small roots embedded in blue clay. The vertical roots were very dark.

The largest roots developing from the trunk of TM had cross-sectional dimensions of $85 \times 140$, $82 \times 140, \quad 85 \times 121$ and $85 \times 110 \mathrm{~mm}$ and extended $135^{\circ}, 90^{\circ}, 0^{\circ}$ and $190^{\circ}$ to $\mathrm{N}$, respectively. The mean ovoidness of these roots was 1.52 (1.291.71). The main vertical root grew in similar fashion to that of TU, flattening when it reached the fragipan without penetrating or anchoring in the fragipan at all. Once radial roots were excised the crown could be slid over the surface of the fragipan.

Cross-sectional dimensions for the largest roots of TL were $95 \times 140,89 \times 129,70 \times 95,67 \times 100$, and $110 \times 162 \mathrm{~mm}$, and their angles of extension from the trunk were $40^{\circ}, 150^{\circ}, 210^{\circ}, 280^{\circ}$ and $335^{\circ}$, respectively. Mean ovoidness of these roots was 1.45 (1.36-1.50). The largest vertical root was $85 \times 154 \mathrm{~mm}$ at the base of the crown but tapered quickly and divided into a very large number of small roots before it reached the fragipan. No vertical roots penetrated the fragipan which was at $1.4 \mathrm{~m}$ depth directly below the crown. For each tree the main 


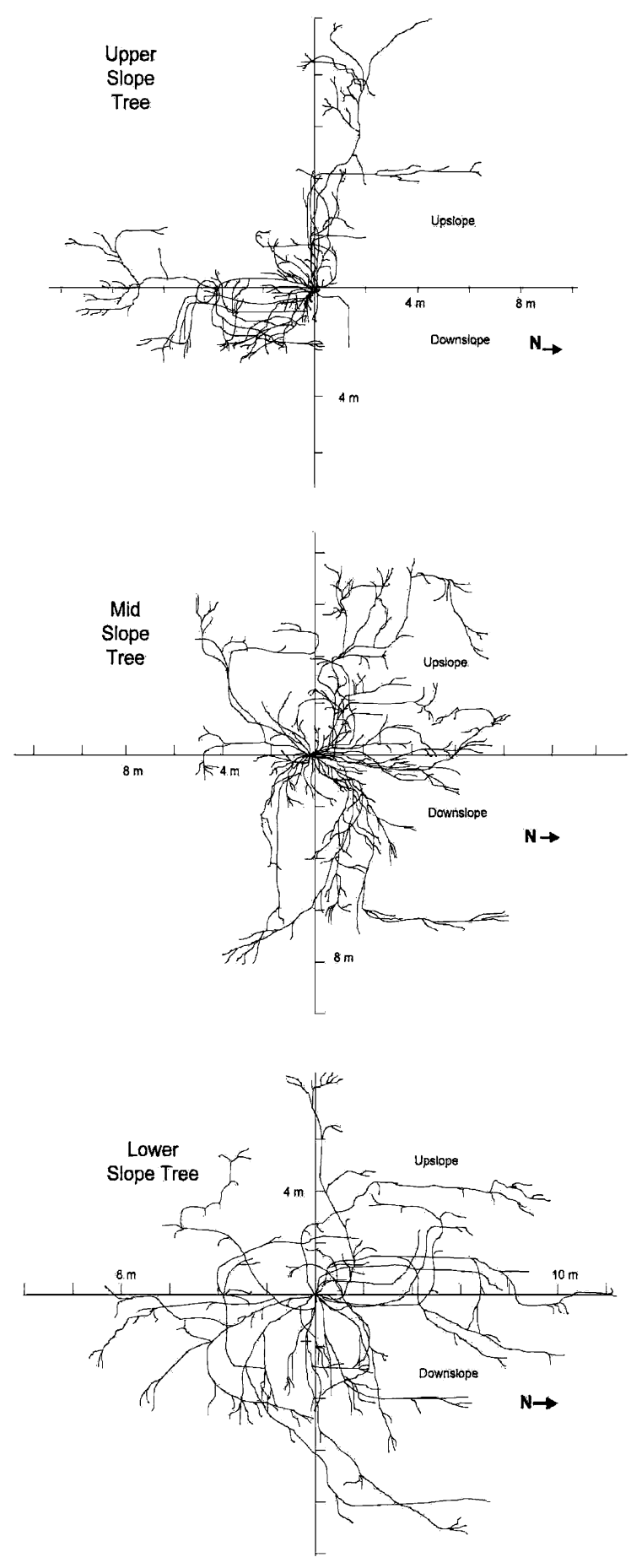

Fig. 1 Radial distribution of coarse roots ( $\geq 2 \mathrm{~mm}$ diameter) of three 'Veronese' poplar trees aged 11.5 year growing on a slope near Palmerston North, New Zealand vertical root was positioned on the downhill side of the crown rather than directly below the centre of the crown.

Relationships between coarse roots and above ground attributes

The relationship between $d b h$ and root mass (Fig. 3a), and between $d b h$ and root length (Fig. 3b) showed that root mass and length can be predicted from $d b h$ with reasonable confidence for trees of different ages and different positions up a slope.The relationship between root mass and $d b h$ is given by the equation:

$$
\begin{aligned}
\log _{10} \text { root mass }= & 3.62 \times \log _{10} d b h \\
& -3.52\left(P<0.01, R^{2}\right. \\
& =0.95, \text { s.e. }(\text { regr. })=0.19)
\end{aligned}
$$

The relationship between root length and $d b h$ is given by the equation:

$$
\begin{aligned}
\log _{10} \text { root length }= & 2.26 \times \log _{10} d b h \\
& -0.18\left(P<0.01, R^{2}\right. \\
& =0.93, \text { s.e. }(\text { regr. })=0.14) .
\end{aligned}
$$

Root:shoot ratio

The $\%$ total root mass represented by the stump was 45, 30 and 18, respectively, for TU, TM and TL. Root:shoot ratio was 0.24 for TU, 0.26 for TM and 0.38 for TL. Corresponding values for root percentage of total DM were 19.2, 20.8 and 27.8.

\section{Discussion}

Root distribution around the trees

The upper slopes on this site had variously eroded since the land was cleared for pastoral farming. Consequently the lower slope is now an accumulation zone for soil that has slipped off the upper slope, and the ridges and hollows of the upper slope have become more exaggerated with subsequent slips. Soil 
Fig. 2 Diagrammatic representation of the growth of roots of a 'Veronese' poplar tree (aged 11.5 year, growing on upper slope) into the underlying fragipan, and root extension uphill and downhill within the rock layers

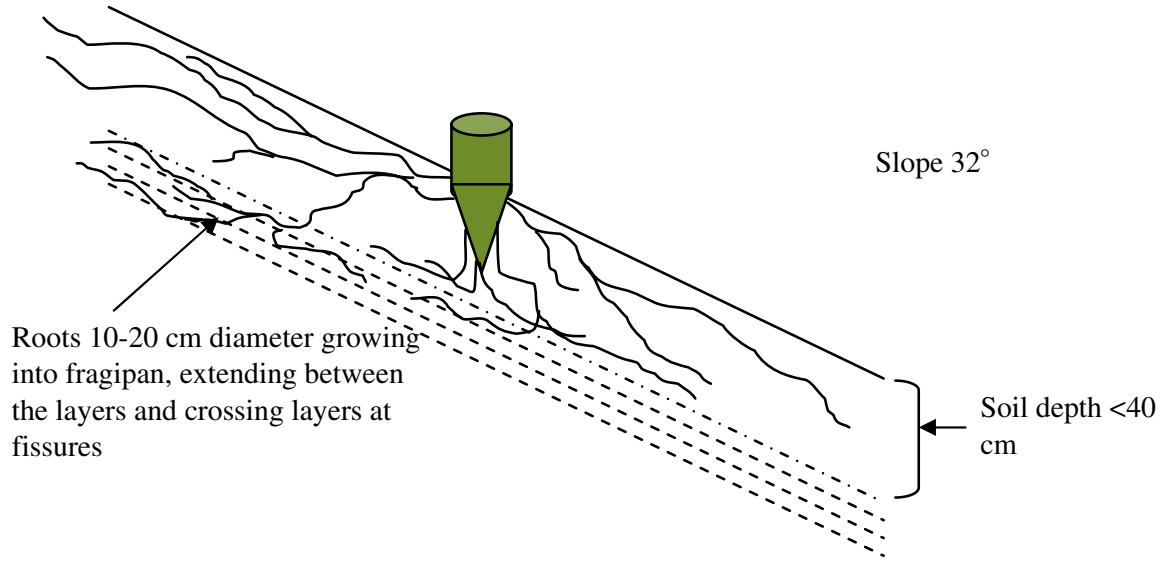

Fig. 3 a Relationship between coarse root ( $\geq 2 \mathrm{~mm}$ diameter) mass and diameter at breast height for six 'Veronese' poplar trees growing on a slope near Palmerston North, New Zealand, incorporating present data $(\diamond)$ and data reported previously ( $\square$ ) for trees aged 5, 7 and 9.5 year (McIvor et al. 2008). b Relationship between coarse root length and diameter at breast height for six Veronese poplar trees growing on a slope near Palmerston North, New Zealand, incorporating present data $(\bullet)$ and data reported previously (ם) for trees aged 5, 7 and 9.5 year (McIvor et al. 2008)
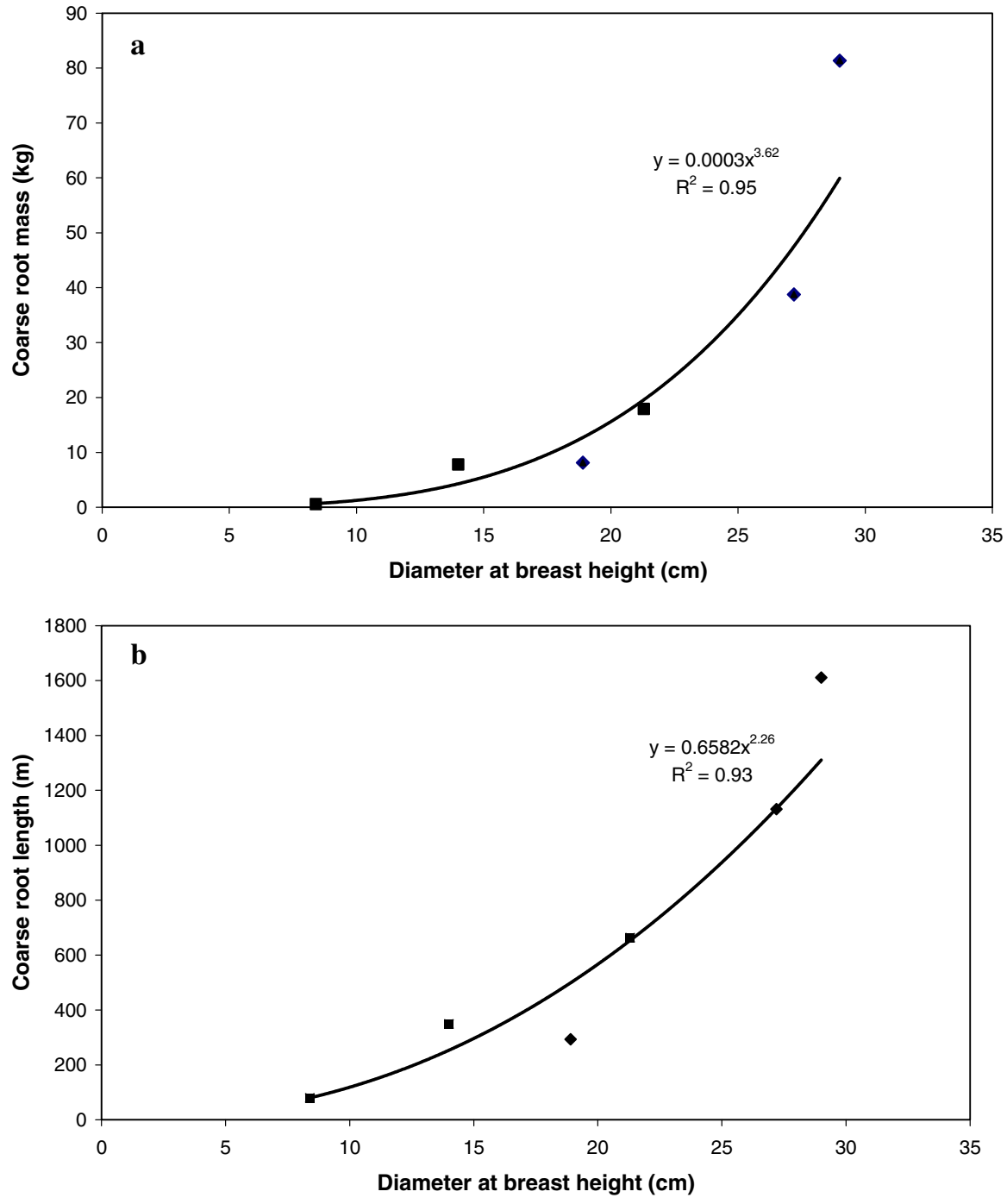
varied in depth across the slope at upper slope and mid-slope positions, creating variability in plantavailable water and drainage which likely influenced the paths which extending roots followed. The VWC was variable and the difference in VWC at $52.5 \mathrm{~cm}$ depth between mid-slope and lower slope positions was likely influenced by local tree root density, the highest VWC at $1.125 \mathrm{~m}$ depth at the lower slope position being correlated with low tree root density at this depth. The buried top soil layer at $1.15 \mathrm{~m}$ on the lower slope is evidence that substantial amounts of eroded soil from the upper slope have accumulated lower down since the land was cleared for pastoral farming, providing both greater soil depth and nutrient supply to TL trees compared with trees growing higher on the slope. The unevenness of the coarse root distribution around TU compared with TM and TL can probably be explained by limitations in soil moisture during the growing season as much as by resistance to stress from slope and wind. The observed root asymmetry was not correlated with the above-ground tree form, which was also found to be asymmetric in all cases, but with the asymmetry explained by exposure to the prevailing westerly wind. Measurements of soil water and soil depth at various positions around individual trees were not conducted, except for soil depth around TU, where upslope roots were more concentrated in locations with greater soil depth. Ganatsas and Spanos (2005) considered that available soil water was the main cause of root asymmetry, contrasting with other workers who concluded that wind is the major determinant of root asymmetry (Coutts et al. 1999; Mickovski and Ennos 2003). Di Iorio et al. (2005) investigated the root system architecture of Quercus pubescens trees aged between 25 and 30 years growing on shallow $\left(4-5^{\circ}\right)$ and steep (14-34 $)$ erosion prone slopes on clayey soils. Root asymmetry was typical of the steep slope trees they excavated and they considered that root asymmetry was a consequence of several environmental factors such as inclination, shallow slides and soil compactness.

The distribution of coarse roots largely within the top $40 \mathrm{~cm}$ of the soil profile concurs with other studies of root distribution in Populus and other tree species (Watson and O'Loughlin 1990; Puri et al. 1994; Burgess et al. 1997; Abernethy and Rutherfurd 2001; Eamus et al. 2002). The asymmetrical root distribution found in this study was also reported by
Puri et al. (1994), who found for Populus deltoides growing at various spacings that the root distribution was asymmetrical or symmetrical, and that root:shoot ratio $(\mathrm{R} / \mathrm{S})$ increased with an increase in spacing (0.15-0.19 from $2 \mathrm{~m} \times 2 \mathrm{~m}$ to $6 \mathrm{~m} \times 6 \mathrm{~m})$. Trees grown at wider spacing allocated proportionally more carbon to their roots than trees grown at narrower spacing. McIvor et al. (2008) reported R/S of 0.16 for a 9.5 year tree from this site. Scarascia-Mugnozza et al. (1997) found R/S varied considerably between different Populus clones, being higher in $P$. deltoides (0.24) than for $P$. trichocarpa (0.13-0 15), although these values were for very young trees and were lower for 2 year trees than for 1 year trees. Malhotra et al. (1985) reported R/S for Pinus patula trees growing in plantations aged 10-14 year of 0.23 or $0.24(n=4)$ which are comparable with the values for similar aged trees in this study, though it is unclear whether these plantations were growing on a slope. R/ $\mathrm{S}$ for the three trees in this study were at the upper end of the literature values, and together with the other reported results suggest that $\mathrm{R} / \mathrm{S}$ can be highly variable and due to factors other than spacing alone. Nielsen and Dencker (1998) reported increasing R/S in Norway spruce trees with wider spacing (increasing thinning intensity), which they considered was best explained by enhanced mechanical stress in stem and coarse roots. Deeper wind penetration and larger canopies in more widely spaced trees release stronger and more frequent bending stress in the roots. Their conclusion was supported by the analysis of radial root ovoidness at $1 \mathrm{~m}$ distance from crown centres although the analysis was not referenced. However, the data presented in this study was insufficient to separate the relative contributions of spacing, wind resistance and slope in determining $\mathrm{R} / \mathrm{S}$.

Poplars have capacity for extensive radial root growth, which is of great benefit in hillslope soil stabilisation. This is the second study in which the extent of root growth has been determined for poplar trees growing on pastoral hillslopes in New Zealand. A comparison of $P . \times$ eumericana 'Veronese' root development with that of Pinus radiata, a forestry species planted extensively on hill country in New Zealand as an alternative to pastoral land use, was discussed earlier (McIvor et al. 2008). However, these sets of data show that root length and biomass can be highly variable for trees of the same age, depending on the site. Root length increased by a 
factor of five and root mass by a factor of ten from TU to TL. TL had twice the root length of plantation Pinus radiata trees aged 25 year (Watson and O'Loughlin 1990), whereas the figure for TM was $140 \%$ and for TU only 37\%. These data provide a useful comparison since Pinus radiata is also used to stabilise hill slopes in New Zealand, usually as forestry plantations. There are no published excavated root data for Pinus radiata growing either at spacings similar to those in this study or at variable slope positions.

Effect of slope steepness on root elongation

Shrestha et al. (2000) in a study with potted woody plants reported that numbers of radial uphill roots and root length increased and downhill roots decreased as the slope increased. Roots growing uphill extended horizontally into the slope whereas downhill roots were typically close to the surface (McIvor et al. 2008). The upwardly growing roots not only play an effective and vital role in stabilising weathered soil strata on steep slopes, they also have important implications for plant growth and survival as they can explore the nutrient-rich layers of the soil without being damaged by exposure (Shrestha et al. 2000). Coutts and Nicoll (1991) found that for Picea sitchensis seedlings there was a tendency for upward growth in long radial roots that developed from the upper part of the root system. When these radial roots approached the soil surface, the tips deflected away from the surface. While the reason for this behaviour was not clear, it did enable the roots to avoid tip desiccation and tap deeper soil for nutrients and moisture. The data from this study was consistent with their explanation. The roots extending directly upwards from TU were mainly found in deeper soil $(>200 \mathrm{~mm})$ in the hollows that form a natural watercourse rather than in the shallower areas $(<12 \mathrm{~mm})$. It is likely that the availability of soil water during the growing season has the greatest influence on where roots extend, hence the position of the upwards extending roots in the deeper soil, and their penetration of the underlying rock in TU. This effect was less apparent for TM and TL roots where the depth of soil and availability of water was much greater. The net result of the extension of roots into the areas where the soil depth and/or soil moisture is greater is that the root length density becomes greater where the soil will wet up more, thus providing greater resistance to soil movement under saturated conditions. Where the tree roots penetrated the underlying bedrock, the anchorage may enhance slope stabilisation (Gray and Solir 1996).

\section{Relationship between root biomass \\ and above-ground data}

A linear relationship between $d b h$ and root biomass was reported by McIvor et al. (2008). However, the additional data reported in this paper clearly indicate the linear relationship only describes the relationship during early tree growth. The regression equation of Tandon et al. (1991) for the relationship between root biomass and $d b h$ for $P$. deltoides $(n=5)$ aged $3-$ 11 year, $\log$ root biomass $=-2.0275+2.5917 \log$ $d b h$ gives a lower value of root biomass for a given $d b h$ than the regression equation determined for this study. This is also true for the studies reported for other tree species in Table 5, all of which were conducted for trees growing in close spaced plantations or forests, Puri et al. (1994) found that the ratio

Table 5 Comparison of regression equations for predicting coarse root ( $\geq 2 \mathrm{~mm}$ diameter) mass from $d b h$ for different tree species

\begin{tabular}{lrllll}
\hline Species & $n$ & $\alpha$ & $\beta$ & $R^{2}$ & Source \\
\hline Populus $\times$ euramericana & 6 & -3.52 & 3.62 & 0.95 & Present study, McIvor et al. (2008) \\
P. deltoides & 5 & -2.03 & 2.59 & 0.95 & Tandon et al. (1991) \\
Picea abies & 42 & -5.90 & 2.85 & 0.92 & Bolte et al. (2004) \\
Fagus sylvatica & 27 & -4.04 & 2.27 & 0.93 & Bolte et al. (2004) \\
Pinus radiata & 247 & -5.01 & 2.73 & 0.97 & Jackson and Chittenden (1981) \\
Pinus radiata & 13 & -2.68 & 2.24 & 0.99 & Watson and O'Loughlin (1990) \\
\hline
\end{tabular}

All equations are of the form $\ln y=\alpha+\beta \ln x$, where $y$ root mass $(\mathrm{kg}), x d b h(\mathrm{~cm}), \alpha$ and $\beta$ are regression coefficients; $n$ sample size. Root mass excludes root crown mass 
of above to below ground biomass decreased with an increase in spacing, i.e. more carbon was allocated to roots in wider-spaced trees. Likewise Fang et al. (2007) found for mixed clone poplar plantations aged 10 years as planting density in stems $\mathrm{ha}^{-1}$ decreased from 1,111 to 500 the root biomass increased from $13.1 \%$ of total biomass to $16.5 \%$. The root:shoot ratios for the four trees at $5 \mathrm{~m} \times 5 \mathrm{~m}$ spacing excavated by Tandon et al. (1991) were 0.13-0.20, the ratio decreasing with tree size, a finding reported by Fang et al. (2007) also. This is in marked contrast to the trees in this study and may be due to the trees at close spacing providing and receiving increased protection from wind as they grow. A high correlation between sapwood area and $d b h$ has been shown for a range of gymnosperm and angiosperm species (Meinzer et al. 2001) suggesting that root biomass/ root length can be determined from $d b h$ for all ages of Veronese poplar. Highly significant correlations between $d b h$ and root biomass and with the crosssection of the structural roots have been shown for Pseudotsuga menziesii up to 37 years (Kuiper and Coutts 1992). However, for wide-spaced poplars growing on pastoral hill slopes a greater variability in root biomass or length can be expected for a given $d b h$ than for close-spaced plantation of forest trees.

The pipe model is a widely used allometric model that describes the functional balance between sapwood area and tree foliage mass (or area) (Berninger et al. 2005; Shinozaki et al. 1964). It is reasonable to expect that the pipe model can describe the functional balance between sapwood area (and $d b h$ ) and fine root mass or area, or coarse root cross-sectional area. As Meinzer et al. (2001) showed $d b h$ can be taken as a proxy for sapwood area, so the regression equations derived in this study are consistent with the allometric relations between tree parts as predicted by the pipe model.

Complete excavation of a tree root system provides invaluable understanding of tree root responses to such aspects as soil, underlying rock, slope and prevailing wind, however, for trees in difficult locations it is very laborious. Other approaches recognise this. Tatsumi et al. (1989) and Van Noordwijk et al. (1994) proposed that the total root lengths of a tree root system can be estimated by taking advantage of the fractal characteristics of tree roots. Smith (2001) found that tree root lengths for Grevillea robusta calculated on the basis of fractal branching rules underestimated root lengths determined by measurements on root samples obtained by soil coring and cautiously suggested that the method may be of practical use in research in which the lengths of individual tree roots are required. An example could be research in soil stabilisation on slopes. Eamus et al. (2002) found for four tree species in a Eucalyptus savanna forest there was a strong relationship between $d b h$ and proximal root size in all species and showed that once the roots were confirmed to be a fractal branching system, the distribution of root size of a tree could be calculated on the basis of the $d b h$ and the fractal parameters. For trees older than those excavated in this study and inaccessible to mechanical excavation means, to gain equivalent data on root biomass and length while reducing the high costs associated with a total root system excavation a combination of modelling as proposed by Noordwijk and sampling techniques such as soil coring or trenching.

Root distribution, particularly lateral extension from the trunk which is significant when considering the zone of soil stabilisation around a wide-spaced tree, may be determined by such environmental factors as soil type, depth, water availability and should be confirmed through exploratory techniques in the field.

\section{Conclusion}

Shallower soil depth and the consequent reduced available water storage capacity are factors likely limiting growth and root development in Populus deltoides $\times$ nigra 'Veronese' trees growing at different positions on an erodible slope. Radial root extension upwards increased with the steepness of the slope. Coarse root length was $>5 \times$ and coarse root biomass $10 \times$ greater for the lower slope tree than for the upper slope tree. A set of regression equations was developed to predict coarse root length and coarse root biomass from $d b h$ for this poplar clone when grown in a wide-spaced situation.

Acknowledgments We are grateful to several students involved in the excavations and measurements. The manuscript was improved by helpful comments from an unknown referee. This research was funded by the Sustainable Land Use Research Initiative, Foundation for Research Science and Technology programme C02X0405. 


\section{References}

Abernethy B, Rutherfurd ID (2001) The distribution and strength of riparian tree roots in relation to riverbank reinforcement. Hydrol Process 15:63-79. doi:10.1002/ hyp. 152

Ball PR, Luscombe PC, Grant DA (1982) Nitrogen on hill country. In: Lynch PB (ed) Nitrogen fertilisers in New Zealand agriculture. New Zealand Institute of Agricultural Sciences, pp 133-147

Berninger F, Coll L, Vanninen P, Mäkelä A, Palmroth S, Nikinmaa E (2005) Effects of tree size and position on pipe model ratios in Scots pine. Can J For Res 35:1294-1304. doi:10.1139/x05-055

Blaschke PM, Trustrum NA, DeRose RC (1992) Ecosystem processes and sustainable land use in New Zealand steeplands. Agric Ecosyst Environ 41:153-178. doi:10.1016/01678809(92)90107-M

Bolte A, Rahmann T, Kuhr M, Pogoda P, Murach D, Gadow KV (2004) Relationships between tree dimension and coarse root biomass in mixed stands of European beech (Fagus sylvatica L.) and Norway spruce (Picea abies [L.] Karst.). Plant Soil 264:1-11. doi:10.1023/B:PLSO.000004 7777.23344.a3

Bransby MF, Davies MCR, Mickovski SB, Sonnenberg R, Bengough AG, Hallett PD (2006) Stabilisation of slopes by vegetation reinforcement. In: Zhang, Wang (eds) Physical modelling in geotechnics-6th ICPMG '06-Ng, (C) 2006 Taylor \& Francis Group, London, ISBN 0-415 41586-1

Burgess PJ, Nkomaula JC, Medeiros Ramos AL (1997) Root distribution and water use in a four-year old silvoarable system. Agrofor Forum 8:15-18

Coutts MP, Nicoll BC (1991) Orientation of the lateral roots of trees 1. Upward growth of surface roots and deflection near the soil surface. New Phytol 119:227-234. doi: 10.1111/j.1469-8137.1991.tb01025.x

Coutts MP, Nielsen CN, Nicoll BC (1999) The development of symmetry, rigidity and anchorage in the structural root system of conifers. Plant Soil 217:1-15. doi:10.1023/A: 1004578032481

Cowie JD (1983) The soils of Ballantrae hill country research station, Woodville. Unpublished New Zealand Soil Bureau report held at AgResearch, Palmerston North

Danjon F, Fourcaud T, Berr D (2005) Root architecture and wind-firmness of mature Pinus pinaster. New Phytol 168:387-400. doi:10.1111/j.1469-8137.2005.01497.x

Davidson DW, Kapustka LA, Koch RG (1991) The role of plant root distribution and strength in moderating erosion of red clay in the Lake Superior watershed. Trans Wisc Acad Sci Arts Lett 77:51-63

De Baets S, Poesen J, Reubens B, Wemans K, De Baerdemaeker J, Muys B (2007) Root tensile strength and root distribution of typical Mediterranean plant species and their contribution to soil shear strength. Plant Soil 305:207-226

Di Iorio A, Lasserre B, Scippa GS, Chiatante D (2005) Root system architecture of Quercus pubescens trees growing on different sloping conditions. Ann Bot (Lond) 95:351-361

Douglas GB, Walcroft AS, Hurst SE, Potter JF, Foote AG, Fung LE, Edwards WRN, van den Dijssel C (2006a)
Interactions between widely spaced young poplars (Populus spp.) and introduced pasture mixtures. Agrofor Syst 66:165-178. doi:10.1007/s10457-005-6641-5

Douglas GB, Walcroft AS, Hurst SE, Potter JF, Foote AG, Fung LE, Edwards WRN, van den Dijssel C (2006b) Interactions between widely spaced young poplars (Populus spp.) and the understorey environment. Agrofor Syst 67:177-186. doi:10.1007/s10457-005-3394-0

Eamus D, Chen X, Kelley G, Hutley LB (2002) Root biomass and root fractal analyses of an open Eucalyptus forest in a savanna of north Australia. Aust J Bot 50:31-41. doi: 10.1071/BT01054

Fang S, Xue J, Tang L (2007) Biomass production and carbon sequestration potential in poplar plantations with different management patterns. J Environ Qual 85:672-679

Fitter AH (2002) Characteristics and functions of root systems. In: Weisel Y, Eshel A, Kafkafi U (eds) Plant roots: the hidden half, 3rd edn. Marcel Dekker, New York, pp 15-32

Friend AL, Mobley JA, Ryan EA, Bradshaw HD (2000) Root growth plasticity of hybrid poplar in response to soil nutrient gradients. J Sustain For 10:133-140. doi:10.1300/ J091v10n01_15

Ganatsas P, Spanos I (2005) Root system asymmetry of Mediterranean pines. Plant Soil 278:75-83. doi:10.1007/ s11104-005-1092-3

Genet M, Kokutse N, Stokes A, Fourcaud T, Cai X, Ji J, Mickovski S (2008) Root reinforcement in plantations of Cryptomeria japonica D. Don: effect of tree age and stand structure on slope stability. For Ecol Man 256:1517-1526. doi:10.1016/j.foreco.2008.05.050

Gottlicher SG, Taylor AFS, Grip H, Betson NR, Valinger E, Hogberg MN, Hogberg P (2008) The lateral spread of tree root systems in boreal forests: estimates based on ${ }^{15} \mathrm{~N}$ uptake and distribution of sporocarps of ectomycorrhizal fungi. For Ecol Man 255:75-81. doi:10.1016/j.foreco. 2007.08.032

Gray DH, Leiser AJ (1982) Biotechnical slope protection and erosion control. Van Nostrand Reinhold, New York, pp 271-278

Gray DH, Solir RB (1996) Biotechnical and soil engineering slope stabilization: a practical guide for erosion control. Wiley, New York

Hazard L, Barker DJ, Easton HS (2001) Morphogenetic adaptation to defoliation and soil fertility in perennial ryegrass (Lolium perenne). NZ J Agr Res 44:1-12

Hewitt AE (1998) New Zealand soil classification. Landcare Research Science Series No. 1, 2nd edn, 133 pp

Jackson DS, Chittenden J (1981) Estimation of dry matter in Pinus radiata root systems. 1. Individual trees. NZ J For Sci 11:164-182

Kuiper LC, Coutts MP (1992) Spatial disposition and extension of the structural root system of Douglas-fir. For Ecol Man 47:111-125. doi:10.1016/0378-1127(92)90269-F

Malhotra PP, Tandon VN, Kumar P (1985) Biomass production, its distribution and biological productivity in Pinus patula, Schl and Cham plantations in Nilgiris. Indian For 111:12-21

McIvor IR, Douglas GB, Hurst SE, Hussain Z, Foote AG (2008) Structural root growth of young Veronese poplars on erodible slopes in the southern North Island, New 
Zealand. Agrofor Syst 72:75-86. doi:10.1007/s10457007-9090-5

Meinzer FC, Clearwater MJ, Goldstein G (2001) Water transport in trees: some current perspectives, new insights and some controversies. Environ Exp Bot 45:239-262. doi: 10.1016/S0098-8472(01)00074-0

Mickovski SB, Ennos AR (2003) Anchorage and asymmetry in the root system of Pinus peuce. Silva Fenn 37:161-173

Mountier NS, Grigg JL, Oomen GA (1966) Sources of error in advisory soil tests. I. Laboratory resources. NZ J Agric Res 9:328-338

Mulia R, Dupraz C (2006) Unusual fine root distributions of two deciduous tree species in southern France: what consequences for modelling of tree root dynamics? Plant Soil 281:71-85. doi:10.1007/s11104-005-3770-6

Nicoll BC, Ray D (1996) Adaptive growth of tree root systems in response to wind action and site conditions. Tree Physiol 16:891-898

Nielsen CN, Dencker I (1998) Root architecture and root/shoot ratios of Norway spruce as affected by thinning density and soil type in Denmark. In: Box JE Jr (ed) Root demographics and their efficiencies in sustainable agriculture, grasslands and forest ecosystems. Kluwer Academic Publishers, Dordrecht, pp 721-736

Puri S, Singh V, Bhushan B, Singh S (1994) Biomass production and distribution of roots in three stands of Populus deltoides. For Ecol Man 65:135-147. doi:10.1016/03781127(94)90165-1

Reubens B, Poesen P, Danjon F, Geudens G, Muys B (2007) The role of fine and coarse roots in shallow slope stability and soil erosion control with a focus on root system architecture: a review. Trees (Berl) 21:385-402. doi: 10.1007/s00468-007-0132-4

Scarascia-Mugnozza GE, Ceulemans R, Heilman PE, Isebrands JG, Stettler RF, Hinckley TM (1997) Production physiology and morphology of Populus species and their hybrids grown under short rotation. II. Biomass components and harvest index of hybrid and parental species clones. Can J For Res 27:285-294

Shinozaki K, Yoda K, Hozumi K, Kira T (1964) A quantitative analysis of plant form: the pipe model theory. I. Basic analyses. Jpn J Ecol 14:97-105

Shrestha MD, Horiuchi M, Yamadera Y, Miyazaki T (2000) A study on the adaptability mechanism of tree roots on steep slopes. In: Stokes A (ed) The supporting roots of trees, woody plants: form, function, physiology. Kluwer Academic Publishers, Dordrecht, pp 51-57

Smith DM (2001) Estimation of tree root lengths using fractal branching rules: a comparison with soil coring for
Grevillea robusta. Plant Soil 229:295-304. doi:10.1023/ A:1004887113229

Snyder KA, Williams DG (2007) Root allocation and water uptake patterns in riparian tree saplings: responses to irrigation and defoliation. For Ecol Man 246:222-231. doi:10.1016/j.foreco.2007.04.032

Statistics NZ (2007) http://www.stats.govt.nz/NR/rdonlyres/ 0B65E72A-2BE0-4D4C-A73C-89EEB35EA9EA/38797/ agriculturalareashectaresbyfarmtype07.xls

Stokes A, Matteck C (1996) Variation in wood strength in tree roots. J Exp Bot 47:693-699. doi:10.1093/jxb/47.5.693

Stokes A, Berthier A, Sacriste S, Martin F (1998) Variations in maturation strains and root shape in root systems of Maritime pine (Pinus pinaster Ait.). Trees (Berl) 12:334-339

Tandon VN, Pandey MC, Rawat HS, Sharma DC (1991) Organic productivity and mineral cycling in plantations of Populus deltoides in Tarai region of Uttar Pradewsh. Indian For 117:596-608

Tatsumi JT, Yamauchi A, Kono Y (1989) Fractal analysis of plant root systems. Ann Bot (Lond) 64:499-503

Van Noordwijk M, Spek LY, de Willigen P (1994) Proximal root diameter as predictor of total root size for fractal branching models. 1. Theory. Plant Soil 164:107-117. doi:10.1007/BF00010116

Waldron LJ, Dakessian S (1981) Soil reinforcement by roots: calculation of increased soil shear resistance from root properties. Soil Sci 132:427-435. doi:10.1097/00010694198112000-00007

Wall AJ, Mackay AD, Kemp PD, Gillingham AG, Edwards WRN (1997) The impact of widely spaced soil conservation trees on hill pastoral systems. Proc NZ Grassland Assoc 59:171-177

Watson A, O'Loughlin C (1990) Structural root morphology and biomass of three age classes of Pinus radiata. NZ J For Sci 20:97-110

Watson A, Phillips C, Marden M (1999) Root strength, growth, and rates of decay: root reinforcement changes of two tree species and their contribution to slope stability. Plant Soil 217:39-47. doi:10.1023/A:1004682509514

Wilkinson AG (1999) Poplars and willows for soil erosion control in New Zealand. Biomass Bioenergy 16:263-274. doi:10.1016/S0961-9534(99)00007-0

Wilson BF (1975) Distribution of secondary thickening in tree root systems. In: Torrey JG, Clarkson DT (eds) The development and function of roots. Academic Press, $618 \mathrm{pp}$

Wu TH, Beal PE, Chinchun L (1988) In-situ shear test of soilroot systems. J Geotech Eng 114:1377-1393 